\title{
Soil Amendments and Rotation Effects on Soybean and Maize Growths and Soil Chemical Changes in Northern Ghana
}

\author{
R. A. L. Kanton, ${ }^{1}$ S. S. J. Buah, ${ }^{1}$ A. Larbi, ${ }^{2}$ A. M. Mohammed, ${ }^{1}$ \\ J. K. Bidzakin, ${ }^{1}$ and E. A. Yakubu ${ }^{1}$ \\ ${ }^{1}$ CSIR, Savanna Agricultural Research Institute, P.O. Box 52, Tamale, Northern Region, Ghana \\ ${ }^{2}$ International Institute of Tropical Agriculture (IITA), Ibadan, Nigeria \\ Correspondence should be addressed to R. A. L. Kanton; ralkanton@gmail.com
}

Received 11 June 2017; Accepted 12 November 2017; Published 3 December 2017

Academic Editor: Othmane Merah

Copyright (C) 2017 R. A. L. Kanton et al. This is an open access article distributed under the Creative Commons Attribution License, which permits unrestricted use, distribution, and reproduction in any medium, provided the original work is properly cited.

\begin{abstract}
A four-year field trial was conducted at Bonia in the Upper East Region of Ghana to evaluate soybean-maize rotation amendment systems. The treatments included soybean without amendment, inoculated soybean, inoculated soybean with fertisol, inoculated soybean with phosphorus and potassium $(\mathrm{P}, \mathrm{K})$, inoculated soybean with $\mathrm{P}, \mathrm{K}$ and fertisol, inoculated soybean with nitrogen, phosphorus, and potassium (N, P, K), and continuous maize. Treatments were arranged in a randomized complete block design with four replications. Inoculation negatively affected yields by $2 \%$ and $14 \%$ in 2013 and 2015, respectively. Soil amendments with P, K or N, P, K increased yields within 45-51\%, fertisol increased by $95 \%$, and integration of P, K and fertisol recorded 76\% increment of inoculated soybean. Yields of maize increased by $1 \%, 20 \%, 25 \%, 43 \%, 44 \%$, and $46 \%$ under inoculated soybean, inoculated soybean with $\mathrm{N}, \mathrm{P}, \mathrm{K}$, inoculated soybean with $\mathrm{P}, \mathrm{K}$, inoculated soybean with fertisol, soybean without amendment, and inoculated soybean with $\mathrm{P}, \mathrm{K}$ and fertisol, respectively. Maize after inoculated soybean with fertisol and maize after inoculated soybean with $\mathrm{P}, \mathrm{K}$ and fertisol consistently scored higher benefit-cost ratio across the two years of experimentation. Thus, the two systems are conceivable for recommendation to the farmers in northern Ghana.
\end{abstract}

\section{Introduction}

Maize (Zea mays L.) and soybean (Glycine max (L.) Merr.) have both become very important food crops and have high economic values in the Upper East Region, evidenced by the number of mouths it feeds and the acreage for cultivation which has outstripped the traditional staple crops of millet and sorghum as it was, before the mid-2000. The government of Ghana and all multilateral and bilateral development partners have all identified maize, soybean, and rice as the crops that can ensure food security and raise the standard of living of the people in northern Ghana. However, poor soil fertility has always been identified by farmers participating in the Annual Review and Planning Sessions organized under the auspices of the Research Extension and Farmer Linkage Committees in the three northern regions of Ghana as the number one constraint to increased and stable crop productivity and production in the Guinea and Sudan Savanna Agroecological Zones.
Although farmers use various improved maize varieties with high yield potential, grain yield has been observed to be very low, rarely exceeding 1 tha $^{-1}$ in farmers' fields [1]. Loss of soil organic matter and nutrients, low water infiltration, and water holding capacity of soils are among the factors that have resulted in poor soil productivity [2]. Increasing population has placed too much pressure on the limited land resources thereby leading to continuous cropping particularly of cereals after cereals [3]. Several soil fertility improvement technologies have not yielded their desired effects in Africa due to the dynamics and contrasting agroecosystems with regards to both socioeconomic and biophysical conditions of the African farming systems $[4,5]$.

Average maize yields per unit of land have fallen in Africa since the 1970s partly because maize production has expanded into drought prone areas and semiarid areas and partly due to declining soil fertility [6]. Low use of chemical fertilizers by farmers with its attendant low yields in maize 
production in Ghana stems from two major factors. These are very prohibitive prices, for example, twenty-five United States of America Dollars (US\$25 for a $50 \mathrm{~kg}$ weight of N, P, $\mathrm{K}$ and about US\$21 for a $50 \mathrm{~kg}$ weight of sulphate of ammonia or sulfan) and the nonavailability of fertilizers when they are most needed. Previous attempts by the Ministry of Food and Agriculture, Global-2000, and other nongovernmental organizations, which started the promotion of maize production, supported farmers with highly subsidized fertilizers. These endeavors appreciably increased average maize yield to 1.2 tha $^{-1}$ from that of 0.6 tha $^{-1}$ under peasant farmers' practice of using $200 \mathrm{~kg} \mathrm{ha}^{-1}$ of N, P, K.

According to Dennis et al. [7], best fertilizer application for savanna soils is a combination of organic and inorganic fertilizers. Application of organic manure and/or compost has been proven to improve soil organic matter content [8] and the available water content of soils by $58-86 \%$ [9]. Increase in wheat yield from $1190 \mathrm{kgha}^{-1}$ in the control to $1520 \mathrm{kgha}^{-1}$ due to the application of municipal solid waste compost resulted because of availability of water in the rooting zone attributable to reduction in evaporation [10].

Crop rotation is well known for its yield improvement effect on crop yield and reduction of financial risk; consequently it is recommended as a countermeasure for financially sustainable crop production [11]. The objective of the current study is to explore and recommend cheaper and reliable sources of and integrated soil fertility management option for maize farmers to boost maize productivity and production on a sustainable basis in the Savanna agroecologies of northern Ghana.

\section{Materials and Methods}

2.1. Experimental Site. The experiments were conducted during the rainy seasons of four consecutive years from 2013 to 2016 at Bonia, a farming community about $2 \mathrm{~km}$ from Navrongo in the Kassena-Nankan Municipal in the Upper East Region $\left(11^{\circ} 01^{\prime} \mathrm{N}, 00^{\circ} 16^{\prime} \mathrm{W}, 249 \mathrm{~m}\right.$ above sea level) in northern Ghana. The mean annual rainfall (2013-2016) of the experimental site was $831 \mathrm{~mm}$, it is monomodal, starting in June and ending in October. The amounts of rainfall during the experimental periods were 473, 330, 531, and $472 \mathrm{~mm}$, respectively, in 2013, 2014, 2015, and 2016 cropping seasons. The distributions were also highly variable within the seasons. The field is a flat land with deep to moderate deep and well drained soils. The soil is developed from granite and has been classified as Plinthic lixisol [12]. The field's cropping history was that it was cropped to maize and the crop residue was left on the surface of the soil in 2011, and in 2012 the field was left to fallow under grass.

2.2. Experimental Materials. The experimental treatments are as follows: Soybean with no soil amendment (control); soybean seeds treated with an inoculants only; soybean seed treated with inoculants plus phosphorus and potassium (60 $\mathrm{P}_{2} \mathrm{O}_{5}$ and $30 \mathrm{~K}_{2} \mathrm{O} \mathrm{kgha}^{-1}$ abbreviated as $\mathrm{P}, \mathrm{K}$ ); soybean treated with inoculants plus fertisol; soybean seed treated with inoculants plus $\mathrm{P}, \mathrm{K}$ plus fertisol and soybean treated with inoculants plus the recommended fertilizer rate of (2560-30 kgha ${ }^{-1}$ as $\mathrm{N}, \mathrm{P}_{2} \mathrm{O}_{5}$, and $\mathrm{K}_{2} \mathrm{O}$, abbreviated as $\mathrm{N}, \mathrm{P}$, $\mathrm{K})$. There was also another control plot where maize was planted after maize, the usual farmers' practice. The test crops are as follows: for soybean variety Jenguma, which is an early maturing soybean variety that is resistant to shattering. Shattering of soybean has been one of the major constraints to soybean production in Ghana. The test variety of maize was the drought tolerant, Striga hermonthica resistant and quality protein maize cv. CSIR-Omankwa, with a maturity period of 90 days, which was released in 2010 .

2.3. Experimental Design and Field Preparation. The experimental design was a randomized complete block with four replications. Plot size for each treatment was $4.5 \mathrm{~m}$ wide by $5 \mathrm{~m}$ long, consisting of 6 ridges. Agronomic data was taken from the middle four ridges.

In 2013, the field was prepared by tractor and was leveled uniformly using hand-held hoes. Triple super phosphate and the organic fertilizer (fertisol) were applied to their respective plots on the 15th of July and worked into the soil before planting. Soybeans were planted on the flat by drilling on the 16th of July 2013. Weeding and reshaping were done as necessary.

In 2014, all the soybean plots were ridged by bullocks at $0.75 \mathrm{~m}$ width. Maize was planted on 18th of July, 2014, on the ridges at $0.40 \mathrm{~m}$ between hills using three to four seeds per hill and thinned to two plants per hill at exactly two weeks after sowing (WAS).

In 2015 maize was rotated with soybean, which was planted on the 22nd of July 2015. Triple super phosphate and fertisol were applied on the 4th of August 2015 to the same plots as it were, in 2013. Weeding and reshaping were done as necessary and harvested on the 7th of November 2015.

In 2016, the soybean again was followed by maize, which was planted on ridges made by bullock at a spacing of $0.75 \mathrm{~m}$ between ridges. The field was sprayed with glyphosate and atrazine before planting. Maize was planted on the 23rd of July 2016. Weeding and reshaping were done as necessary and harvested on 26th of October 2016.

The maize crop was fertilized by hill placement method at two weeks after sowing at the rate of $60 \mathrm{~N} \mathrm{kgha}^{-1}$ as urea, $60 \mathrm{P}_{2} \mathrm{O}_{5} \mathrm{kgha}^{-1}$ as triple super phosphate (TSP), and $60 \mathrm{~K}_{2} \mathrm{O} \mathrm{kgha}^{-1}$ as muriate of potash (MOP). Top-dressing was done with sulfan, an improved version of sulphate of ammonia with high nitrogen and sulfur at the rate of 40 $\mathrm{Nkgha}^{-1}$ for all treatments at two weeks after the first fertilizer application. All other agronomic practices were as recommended for maize cultivation in Ghana.

2.4. Soil Sampling and Fertisol Analysis. Initial soil samples were taken from 20 to 25 points distributed along the diagonal transects of the experimental area at $0-15 \mathrm{~cm}$ depths, a month to the start of the year, 2013, farming season. Final sampling was done according to treatment plots after the 2016 harvest. The samples collected from each plot were composited according to depths, air-dried, crushed, and sieved through a $2 \mathrm{~mm}$ sieve and sent to the soil chemistry 
TABLE 1: Chemical composition of fertisol, initial soil, and the soils after four years of treatment.

\begin{tabular}{|c|c|c|c|c|}
\hline Treatment & $\mathrm{pH}$ & $\mathrm{N}$ & OC & $\begin{array}{c}\mathrm{P} \\
\mathrm{mgkg}^{-1}\end{array}$ \\
\hline Fertisol & 8.0 & 19.7 & 140 & 12795 \\
\hline Initial soil & 4.6 & 0.60 & 3.5 & 13.6 \\
\hline \multicolumn{5}{|l|}{ Soil after four years } \\
\hline Maize after maize & 5.0 & 0.31 & 4.0 & 26.3 \\
\hline Maize after noninoculated soybean & 5.2 & 0.35 & 4.4 & 31.5 \\
\hline Maize after inoculated soybean & 5.2 & 0.37 & 4.7 & 29.0 \\
\hline Maize after inoculated soybean $+\mathrm{P}, \mathrm{K}$ & 5.5 & 0.39 & 4.8 & 33.8 \\
\hline Maize after inoculated soybean + fertisol & 5.5 & 0.34 & 4.4 & 29.6 \\
\hline Maize after inoculated soybean $+\mathrm{N}, \mathrm{P}, \mathrm{K}$ & 5.2 & 0.40 & 4.9 & 50.9 \\
\hline Maize after inoculated soybean $+\mathrm{P}, \mathrm{K}+$ fertisol & 5.4 & 0.39 & 4.7 & 44.5 \\
\hline
\end{tabular}

laboratory of CSIR-SARI for chemical analysis. The sieved $(<2 \mathrm{~mm}$ mesh) air-dried samples were analyzed for $\mathrm{pH}$ in water using soil to water ratio of $1: 2.5$ [13]. Total $\mathrm{N}$ was determined by Kjeldahl distillation and titration method [14]. Available P was measured using the Bray and Kurtz method [15] and organic carbon was determined by modified Walkley and Black procedure as outlined in Nelson and Sommers [16]. The micro-Kjeldahl digestion procedure was used to determine the fertisol's $\mathrm{N}$, and $\mathrm{P}$ [14], whilst organic carbon was by the wet digestion method outlined by Nelson and Sommers [16].

2.5. Statistical Analysis. Agronomic data collected included crop growth, development, grain yield, and its components and biomass. All crop data were subjected to analysis of variance (ANOVA) using GENSTAT Statistical Package 9th Edition and where there were significant differences among treatments, means were separated using the LSD test at the $P=0.01$ or 0.05 levels.

2.6. Economic Analyses. Complete budgets were constructed to calculate the total variable cost, estimate gross and net benefits, and calculate benefit-cost ratios which will help to identify economically viable treatments. Data was taken from on-farm trials and through market surveys. The parameters measured included input prices, produce prices, agronomic practices, input used, and labour used $[17,18]$.

2.6.1. Benefit-Cost Ratio (BCR). Cost-benefit analysis (CBA), sometimes called benefit-cost analysis (BCA), is a systematic approach to estimating the strengths and weaknesses of alternatives; it is used to determine options that provide the best approach to achieve benefits whilst preserving savings. The CBA is also defined as a systematic process for calculating and comparing benefits and costs of alternative projects (treatments).

Broadly, CBA has two main purposes:

(1) To determine if an investment/decision is sound (justifiable/feasible), verifying whether its benefits outweigh the costs, and by how much
(2) To provide a basis for comparing projects (treatments), which involves comparing the total expected cost of each treatment against its total expected benefits.

Calculation of benefit-cost ratio (BCR) is formulated as shown below:

$$
\mathrm{CBA}=\frac{\Delta \mathrm{TB}}{\Delta \mathrm{TC}},
$$

where $\Delta \mathrm{TB}$ is change in total benefits and $\Delta \mathrm{TC}$ is change in total cost.

All treatments with a CBR equal to or greater than $1(\geq 1)$ should be accepted.

\section{Results}

3.1. Soil Chemical Changes. The mean physical and chemical properties of the surface soil taken at a depth of $0-15 \mathrm{~cm}$ before the start of the experiment (initial soils) after harvest of maize in 2016 are presented in Table 1. The soils of the experimental site were mainly acidic, with low $\mathrm{pH}$ of 4.6. The organic carbon content was $3.5 \mathrm{~g} \mathrm{~kg}^{-1}$, which is low. The corresponding total nitrogen content was characteristically low $\left(0.6 \mathrm{~g} \mathrm{~kg}^{-1}\right)$. The available phosphorus (Bray-1) of $13.6 \mathrm{mgkg}^{-1}$ is deemed sufficient for crop growth in these soils. After 4 years of this study, tremendous nutrient changes occurred in the soils. The soil nutrient contents generally recorded pronounced increases of $\mathrm{pH}, \mathrm{P}$, and organic carbon in soybean plots compared to the continuous plots. There was a sharp decline in $\mathrm{N}$ relative to the initial soil $\mathrm{N}$ content (Table 1). Based on the chemical properties of the fertisol added (Table 1), the $\mathrm{pH}$ value being greater than the neutral $\mathrm{pH}$ of 7 indicated its tendency to ameliorate the acidic soils. The fertisol contained extremely high amounts of $\mathrm{P}$ to improve the low $\mathrm{P}$ content of the soils.

3.2. Soybean Performances. The results in 2013 cropping season indicate that the soybean grain yield and some of its growth components were significantly $(P<0.01)$ affected by treatment effects. Noninoculated soybean took significantly $(P<0.05)$ longer days to reach $50 \%$ bloom than inoculated 
TABLE 2: Soybean growth and development as affected by inoculation and soil amendments in the northern savanna of Ghana.

\begin{tabular}{|c|c|c|c|}
\hline Treatment & $\begin{array}{c}\text { Plant height } \\
(\mathrm{cm})\end{array}$ & $\begin{array}{c}100 \text { seeds } \\
(\mathrm{g})\end{array}$ & H. I. ${ }^{\mathrm{a}}$ \\
\hline \multicolumn{4}{|l|}{2013} \\
\hline Soybean & 31.9 & 11.5 & 0.34 \\
\hline Soybean + inoculants & 35.7 & 10.3 & 0.32 \\
\hline Soybean + inoculants $+\mathrm{P}, \mathrm{K}$ & 41.2 & 10.8 & 0.39 \\
\hline Soybean + inoculants + fertisol & 40.9 & 11.8 & 0.36 \\
\hline Soybean + inoculants $+\mathrm{P}, \mathrm{K}+$ fertisol & 40.2 & 11.5 & 0.36 \\
\hline Soybean + inoculants $+\mathrm{N}, \mathrm{P}, \mathrm{K}$ & 39.0 & 11.5 & 0.37 \\
\hline s.e.d & 3.8 & 0.50 & 0.04 \\
\hline C.V. $(\%)$ & 14.2 & 6.6 & 14.6 \\
\hline \multicolumn{4}{|l|}{2015} \\
\hline Soybean & 39.8 & 9.7 & 0.20 \\
\hline Soybean + inoculants & 35.5 & 11.0 & 0.21 \\
\hline Soybean + inoculants $+\mathrm{P}, \mathrm{K}$ & 42.5 & 11.2 & 0.21 \\
\hline Soybean + inoculants + fertisol & 48.0 & 11.0 & 0.21 \\
\hline Soybean + inoculants $+\mathrm{P}, \mathrm{K}+$ fertisol & 48.8 & 10.8 & 0.21 \\
\hline Soybean + inoculants $+\mathrm{N}, \mathrm{P}, \mathrm{K}$ & 64.5 & 9.7 & 0.17 \\
\hline s.e.d. & 5.3 & 0.6 & 0.0 \\
\hline $\mathrm{CV}(\%)$ & 11.3 & 7.5 & 9.3 \\
\hline
\end{tabular}

${ }^{\mathrm{a}} \mathrm{H} . \mathrm{I} . \mathrm{=}$ harvest index.

soybean with either $\mathrm{P}, \mathrm{K}$, fertisol, or both soil amendments (Table 2). Although inoculated soybean alone and that with recommended $\mathrm{N}, \mathrm{P}, \mathrm{K}$ recorded shorter days, they were not statistically different from noninoculated soybeans and so were they with inoculated soybean with either P, K, or fertisol or both soil amendments (Table 2). Soybean height was not significantly $(P>0.05)$ affected by treatment. Yield components including plant stands (number of plants per ha), 100-seed weight, and harvest indices were not significantly $(P>0.05)$ different among the treatments.

Repeating the same treatments in 2015 as in 2013, the results again indicate that the soybean grain yield and some of its growth components were significantly $(P<0.01)$ affected by the effects of the treatments. Inoculated soybean with application of N, P, K produced the taller plants, which were significantly $(P<0.05)$ taller than the rest of the treatments (Table 2). Inoculated soybean with application of $\mathrm{P}, \mathrm{K}$ resulted in the highest harvest index, which was significantly $(P<$ 0.05 ) higher than those recorded when soybean was not inoculated and when soybean was inoculated without an amendment (Table 2).

Soybean yields in 2013 were $901,886,1361,1758,1583$, and $1304 \mathrm{kgha}^{-1}$ for noninoculated soybean, inoculated soybean, inoculated soybean with $\mathrm{P}, \mathrm{K}$, inoculated soybean with application of fertisol, inoculated soybean plus P, K plus fertisol, and inoculated soybean with application of recommended $\mathrm{N}$, P, K treatments, respectively (Figure 1). Inoculated soybean with the application of fertisol produced the highest grain yield and inoculated soybean the lowest (Figure 1). Inoculated soybean with the application of fertisol produced significantly $(P<0.05)$ higher grain yield than those obtained for the rest of the treatments with the exception of inoculated soybean with application of $\mathrm{P}, \mathrm{K}$ and fertisol (Figure 1).

Soybean yields in 2015 were 696, 599, 668, 894, 783, and $711 \mathrm{kgha}^{-1}$ for the treatments: noninoculated soybean, inoculated soybean, inoculated soybean with P, K, inoculated soybean with application of fertisol, inoculated soybean plus $\mathrm{P}, \mathrm{K}$ plus fertisol, and inoculated soybean with application of recommended N, P, K, respectively (Figure 1). Inoculated soybean with application of fertisol again produced the highest grain yield, whilst inoculated soybean without any amendment gave the least grain yield (Figure 1). Yields of the soybean in 2015 were generally very low when compared with that of 2013. In both years, inoculated soybean with the application of fertisol produced significantly $(P<0.05)$ higher grain yield than those obtained for the rest of the treatments with the exception of inoculated soybean with application of $\mathrm{P}, \mathrm{K}$ and fertisol (Figure 1).

3.3. Maize Performances. Maize after maize indicated to prolong the days taken by the maize crop to reach $50 \%$ bloom as compared with maize following inoculated soybean with $\mathrm{P}$, K or fertisol or both soil amendments (Table 3). The reduction in days to $50 \%$ bloom of maize was more pronounced in fields preceded with inoculated soybean with $\mathrm{P}, \mathrm{K}$ and fertisol amended soils (Table 3). However, maize after noninoculated soybean and inoculated soybean plus the recommended fertilizer took similar days to attain $50 \%$ bloom as that of maize after maize. Maize plants after inoculated soybean with application of fertisol or $\mathrm{P}, \mathrm{K}$ resulted in bigger stems, whilst maize plants after noninoculated soybean produced the tiniest stems (Table 3). Maize after inoculated soybean with 
TABLE 3: Maize growth and development as affected by amended soybean rotation fields in the northern savanna of Ghana.

\begin{tabular}{|c|c|c|c|c|c|}
\hline Treatment & $\begin{array}{c}50 \% \text { bloom } \\
\text { (d) }\end{array}$ & Stem girth & $\begin{array}{l}\text { Cob diameter } \\
(\mathrm{mm})\end{array}$ & $\begin{array}{c}100 \text { seeds } \\
(\mathrm{g})\end{array}$ & H. I. ${ }^{\mathrm{a}}$ \\
\hline \multicolumn{6}{|l|}{2014} \\
\hline Maize after maize & 50 & 16.1 & 40.9 & 23.6 & 0.50 \\
\hline Maize after non-inoculated soybean & 51 & 13.8 & 39.9 & 22.8 & 0.52 \\
\hline Maize after inoculated soybean & 51 & 15.0 & 40.4 & 24.3 & 0.58 \\
\hline Maize after inoculated soybean $+\mathrm{P}, \mathrm{K}$ & 48 & 16.6 & 42.2 & 24.1 & 0.52 \\
\hline Maize after inoculated soybean + fertisol & 48 & 17.4 & 43.2 & 26.6 & 0.54 \\
\hline Maize after inoculated soybean $+\mathrm{N}, \mathrm{P}, \mathrm{K}$ & 51 & 15.3 & 40.6 & 24.0 & 0.57 \\
\hline Maize after inoculated soybean $+\mathrm{P}, \mathrm{K}+$ fertisol & 44 & 16.2 & 43.1 & 24.9 & 0.52 \\
\hline s.e.d. & 1.4 & 1.2 & 1.1 & 0.9 & 0.0 \\
\hline C.V. $(\%)$ & 4.0 & 10.6 & 4.0 & 5.3 & 6.2 \\
\hline \multicolumn{6}{|l|}{2016} \\
\hline Maize after maize & 52 & 18.5 & 41.4 & 23.6 & 0.37 \\
\hline Maize after noninoculated soybean & 51 & 18.3 & 41.1 & 22.8 & 0.45 \\
\hline Maize after inoculated soybean & 53 & 17.9 & 40.6 & 24.5 & 0.36 \\
\hline Maize after inoculated soybean $+\mathrm{P}, \mathrm{K}$ & 53 & 17.6 & 43.0 & 23.1 & 0.39 \\
\hline Maize after inoculated soybean + fertisol & 54 & 17.2 & 42.2 & 26.8 & 0.41 \\
\hline Maize after inoculated soybean $+\mathrm{N}, \mathrm{P}, \mathrm{K}$ & 54 & 18.9 & 42.2 & 25.0 & 0.35 \\
\hline Maize after inoculated soybean $+\mathrm{P}, \mathrm{K}+$ fertisol & 52 & 19.5 & 42.0 & 24.5 & 0.41 \\
\hline s.e.d. & 0.8 & 1.4 & 1.7 & 1.0 & 0.0 \\
\hline $\mathrm{CV}(\%)$ & 2.2 & 10.9 & 5.6 & 4.3 & 13.7 \\
\hline
\end{tabular}

${ }^{\mathrm{a}} \mathrm{H}$. I. = harvest index.

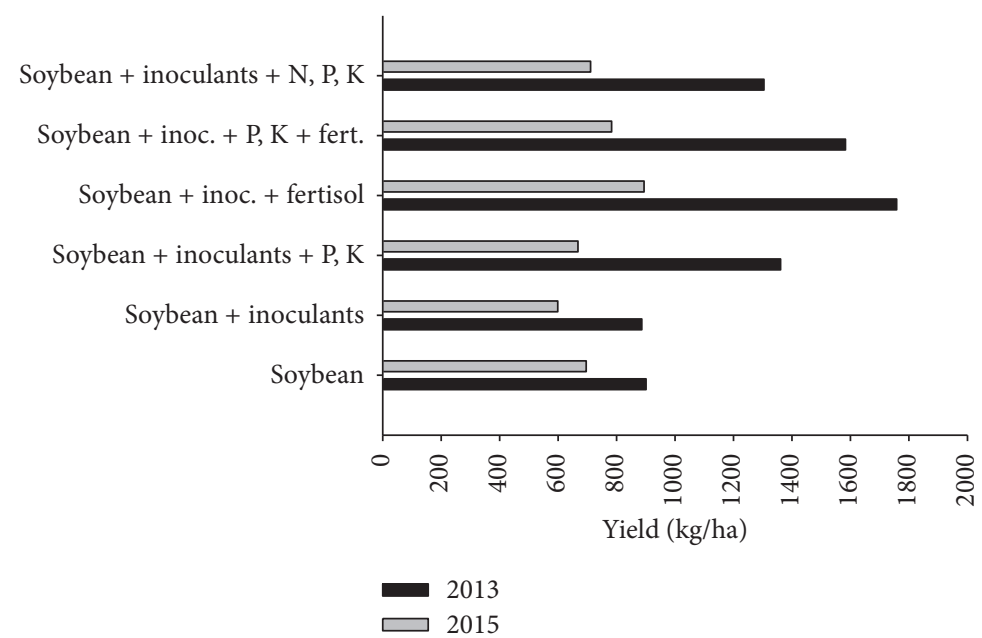

FIGURE 1: Grain yield of soybean as affected by soil amendments in the 2013 and 2015 cropping seasons in the northern savanna of Ghana. inoc.: inoculants and fert: fertisol.

fertisol produced significantly $(P<0.05)$ bigger cobs than the rest of the treatments (Table 2). Maize after inoculated soybean with fertisol produced the boldest kernels, which were superior to those produced by the rest of the treatments except for maize after inoculated soybean and recommended fertilizer (Table 3). Maize after inoculated soybean recorded the highest harvest index, which was significantly $(P<0.05)$ greater than the rest of the treatments (Table 3 ).

Generally, maize grain yields recorded for this study are far greater than those normally obtained by farmers. In the
2014 cropping season, maize grain yields were 3250, 2333, $2250,3292,3458,2333$, and $3221 \mathrm{kgha}^{-1}$ for continuous maize, maize after noninoculated soybean, maize after inoculated soybean, maize after inoculated soybean with $\mathrm{P}, \mathrm{K}$ maize after inoculated soybean with fertisol, maize after inoculated soybean plus $\mathrm{P}, \mathrm{K}$ and fertisol, and maize after inoculated soybean and recommended N, P, K, respectively (Figure 2). Maize after inoculated soybean with application of fertisol produced the highest grain yield, which is significantly $(P<0.01)$ higher than those recorded for maize after 


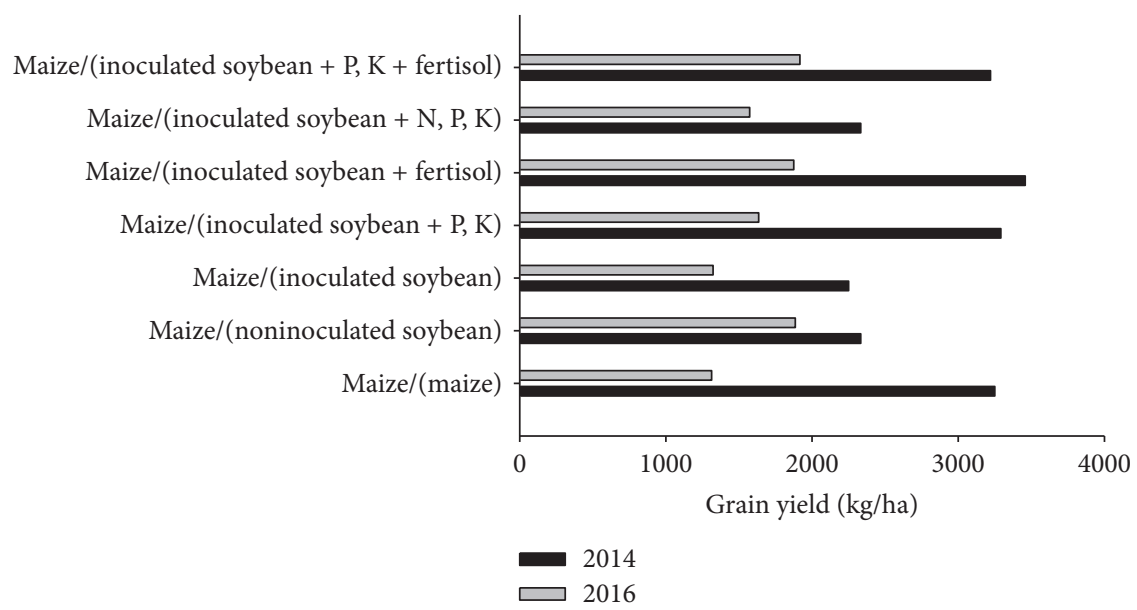

FIGURE 2: Grain yield of maize as affected by amended soybean rotations in the 2014 and 2016 cropping seasons in the northern savanna of Ghana. inoc.: inoculants and fert: fertisol.

noninoculated soybean, inoculated soybean, and inoculated soybean with recommended fertilizer (Figure 2).

Results of maize performance in 2016 that followed the cropping of soybean with different amendments varied significantly $(P<0.05)$ in yield components including days to $50 \%$ bloom, 100-kernel weight, and harvest index (Table 2). Maize after noninoculated soybean attained 50\% bloom significantly $(P<0.05)$ earlier than maize after inoculated soybean with recommended fertilizer rate for soybean and maize after inoculated soybean plus $\mathrm{P}, \mathrm{K}$ or fertisol (Table 3). Maize after noninoculated soybean was the earliest to bloom whilst maize after inoculated soybean with recommended fertilizer for soybean was the latest to bloom (Table 3).

Variations in the maize stem girth, size of cobs produced, and 100-kernel weight of maize were not significantly $(P>$ 0.05 ) affected by the initial soybean treatment before planting the maize. Maize after sole soybean recorded the highest harvest index followed closely by maize after inoculated soybean with fertisol and maize after P, K and fertisol, whilst maize after inoculated soybean with the recommended fertilizer recorded the lowest harvest index (Table 3).

Maize yields were 1313, 1885, 1323, 1635, 1875, 1817, and $1573 \mathrm{kgha}^{-1}$, respectively, in 2016 for continuous maize, maize after noninoculated soybean, maize after inoculated soybean, maize after inoculate soybean with $\mathrm{P}, \mathrm{K}$, maize after inoculated soybean with fertisol, maize after inoculated soybean plus $\mathrm{P}, \mathrm{K}$ and fertisol, and maize after inoculated soybean and recommended N, P, K, respectively (Figure 2). Maize after inoculated soybean plus $\mathrm{P}, \mathrm{K}$ and fertisol produced the highest grain yield followed closely by maize after inoculated soybean with fertisol, whilst maize after maize resulted in the lowest grain yield (Figure 2).

3.4. Economic Analyses. Table 4 shows the results of benefitcost ratio analyses of soybean and maize rotation under different soil amendments. All treatments had a benefit-cost ratio (BCR) greater than one in 2014. Therefore, all treatments were profitable to farmers. Maize after inoculated soybean and fertisol recorded the highest BCR of 2.0 which implies higher profit or net returns than the rest of the treatments. Maize after inoculated soybean plus $\mathrm{P}, \mathrm{K}$ is the second most profitable treatment with its benefit-cost ratio of 1.8; the third most profitable treatment is maize after inoculated soybean plus $\mathrm{P}, \mathrm{K}$ and recommended fertilizer which has a benefitcost ratio 1.7. The treatment with the lowest BCR is maize after noninoculated soybean with a ratio of 1.3.

Similarly, all the treatments in 2016 had a benefit-cost ratio greater than one and were therefore economically profitable to farmers (Table 4). Maize after inoculated soybean plus $\mathrm{P}, \mathrm{K}$ and recommended fertilizer scored the highest BCR of 1.5, followed by maize after noninoculated soybean and maize after inoculated soybean and fertisol all scoring the same BCR of 1.4. Maize after maize scored the least BCR of 1.0 .

\section{Discussion}

This study has amply demonstrated that inoculation of soybean with the application of soil amendments such as fertisol and phosphorus and potassium fertilizers has the potential to increase both soybean and maize productivity and production in the semiarid agroecologies of the tropics on a sustained basis. In general, soybeans and maize grain and biomass yields were significantly affected by both treatment effect and rainfall. Figure 1 showed clear variations in the amount of rainfall received and its distribution. Mean soybean yields recorded in 2013 was about 1.79 times greater than that recorded in 2015 due to better rainfall distribution. Similarly, maize grain and biomass yields in 2014 were about 1.96 times higher than those recorded in 2016, also due to better distribution of rainfall in 2014.

Inoculation of soybean affected yield negatively by $2 \%$ in 2013 whilst soil amendments increased yields by $45 \%, 51 \%$, $76 \%$, and $95 \%$ and for inoculated soybean with application of recommended $\mathrm{N}, \mathrm{P}, \mathrm{K}$, inoculated soybean with $\mathrm{P}, \mathrm{K}$, inoculated soybean plus $\mathrm{P}, \mathrm{K}$ plus fertisol, and inoculated soybean with application of fertisol, respectively. Clearly, 
TABLE 4: Economic benefits of soybean and maize rotation under different soil amendments in the northern savanna of Ghana.

\begin{tabular}{|c|c|c|c|c|}
\hline Treatments & Gross benefit GHS $^{\mathrm{a}}$ & Total variable cost GHS & Net benefit GHS & Benefit/cost ratio \\
\hline \multicolumn{5}{|l|}{2014} \\
\hline Maize after maize & 2710 & 1624 & 1087 & 1.7 \\
\hline Maize after noninoculated soybean & 1983 & 1551 & 432 & 1.3 \\
\hline Maize after inoculated soybean & 2437 & 1596 & 841 & 1.5 \\
\hline Maize after inoculated soybean $+\mathrm{P}, \mathrm{K}$ & 2900 & 1643 & 1258 & 1.8 \\
\hline Maize after inoculated soybean + fertisol & 3294 & 1682 & 1612 & 2 \\
\hline Maize after inoculated soybean $+\mathrm{N}, \mathrm{P}, \mathrm{K}$ & 2497 & 1602 & 895 & 1.6 \\
\hline Maize after inoculated soybean $+\mathrm{P}, \mathrm{K}+$ fertisol & 2820 & 1635 & 1186 & 1.7 \\
\hline \multicolumn{5}{|l|}{2016} \\
\hline Maize after maize & 1576 & 1510 & 66 & 1 \\
\hline Maize after noninoculated soybean & 2262 & 1579 & 683 & 1.4 \\
\hline Maize after inoculated soybean & 1588 & 1511 & 76 & 1.1 \\
\hline Maize after inoculated soybean $+\mathrm{P}, \mathrm{K}$ & 1962 & 1549 & 413 & 1.3 \\
\hline Maize after inoculated soybean + fertisol & 2250 & 1578 & 673 & 1.4 \\
\hline Maize after inoculated soybean $+\mathrm{N}, \mathrm{P}, \mathrm{K}$ & 1888 & 1541 & 346 & 1.2 \\
\hline Maize after inoculated soybean $+\mathrm{P}, \mathrm{K}+$ fertisol & 2300 & 1583 & 718 & 1.5 \\
\hline
\end{tabular}

${ }^{\mathrm{a}} \mathrm{GHS}=$ Ghana cedis; $1 \mathrm{U} \$=3.9$ GHS.

addition of inorganic fertilizer increased inoculated soybean yield within $45-51 \%$ whilst organic fertilizer increased the same by $95 \%$ and the integration of organic and inorganic was by $76 \%$ yield increment. The yield enhancement ability of organic fertilizer application has been noted by other researchers and attributed to water retention in the root zone due to reduction in evaporation [10].

Relative to yields in 2013, soybean yields in 2015 were very low and so the effects of the treatments were lowly pronounced. Yields of soybean declined by $14 \%$ and $4 \%$ in inoculated soybean and inoculated soybean with $\mathrm{P}, \mathrm{K}$ treatments but increased by $2 \%, 13 \%$, and $28 \%$ in inoculated soybean with application of recommended N, P, K, inoculated soybean with $\mathrm{P}, \mathrm{K}$, and fertisol, and inoculated soybean with application of fertisol, respectively, in 2015. These trends have been consistent over the period of the study, in both seasons of normal rainfall distribution and those that rainfall distribution was not normal. Soybean plants were taller for treatments that were inoculated and also received either fertisol or P, K. This superior performance could be ascribed to enhanced uptake of nutrient afforded by these soil amendments.

Several workers have come to the conclusion that the integration of organic and inorganic soil amendments enhances fertilizer use efficiency, which results in a balanced release of nutrients to the maize crop $[19,20]$. It has been demonstrated that supplementary fertilization can lead to improved performance of these crops [21]. In the present study inoculation of soybean gave consistently lower grain yields compared with noninoculated soybean. This is in sharp contrast with Otieno et al. [22] who found no yield increment due to inoculation of soybeans.

The inoculation of soybeans and the application of a soil amendment such as fertisol and $\mathrm{P}, \mathrm{K}$ resulted in higher grain and biomass yields of both soybean and maize. This could be ascribed to the enrichment in soil nutrients and soil organic matter that might have resulted in better supply of plant nutrients and moisture for better crop growth and development. This is in sharp agreement with Kapkiyai et al. [23] who reported that the combination or organic and inorganic nutrient sources resulted in synergy and enhanced synchronization of nutrient release and absorption resulting in higher crop yields.

Relative to continuous maize cropping, rotation effects on maize yields increased the grain yields by $44 \%, 1 \%, 25 \%$, $43 \%, 20 \%$, and $46 \%$ when maize followed noninoculated soybean, inoculated soybean, inoculated soybean $+\mathrm{P}, \mathrm{K}$, inoculated soybean + fertisol, inoculated soybean $+\mathrm{N}, \mathrm{P}$, $\mathrm{K}$, and inoculated soybean $+\mathrm{P}, \mathrm{K}+$ fertisol, respectively. The lower maize yields obtained for the maize after maize plot are in consonance with the work of Ofori and Stern [24] who asserted that cereals following grain legumes often recorded greater grain yields than those of cereal after cereal. Bowen [25] suggested that a major reason for the higher yields of maize after cowpea was an $\mathrm{N}$ residual effect from the legume. This could also be the probable reason why the maize preceding the soybean had superior grain and biomass yields. The maize grain yields reported in the present study, with the use of an improved maize variety with the application of an integrated soil fertility management system, have shown that maize yields could be increased drastically above the $1.1 \mathrm{~kg}$ per ha as reported by Abunyewa and Mercer-Quarshie [1].

Further, comparison of 2014 and 2016 data revealed all treatments were economically viable; however, the treatments, inoculated soybean plus fertisol and inoculated soybean plus $\mathrm{P}, \mathrm{K}$ plus fertisol, were consistent across the two years scoring the highest BCR across the two years that the study was conducted. 


\section{Conclusion}

Maize following inoculated soybean with soil amendments enhanced the grain and straw yields when compared with continuous maize or precropped soybean with no soil amendment. Among the inoculated soybean with soil amendment systems, inoculated soybean plus fertisol and inoculated soybean plus $\mathrm{P}, \mathrm{K}$ plus fertisol recorded high grain yields in both soybean-maize crops. Additionally, the two treatments consistently scored high benefit-cost ratio across the two years of experimentation. Thus, they appeared recommendable for maize farmers in northern savanna of Ghana.

\section{Conflicts of Interest}

The authors declare that there are no conflicts of interest regarding the publication of this paper.

\section{Acknowledgments}

The authors are grateful to the USAID Feed the Future Project, for the provision of funds through the IITA under the Africa Rising Project of the USAID without which this study would not have been possible. The support by Field Technicians of the CSIR-SARI, Manga Station, in data collection is also gratefully acknowledged. The authors would also like to thank the staff of the Kassena-Nankana Municipal Directorate of the Ministry of Food and Agriculture for their cooperation and support in the acquisition of land and organization of field days. Also, they thank the Director of the CSIR-SARI for his kind permission for this work to be published.

\section{References}

[1] A. A. Abunyewa and H. Mercer-Quarshie, "Response of maize to magnesium and zinc application in the semi-arid zone of West Africa," Asian Journal of Plant Sciences, vol. 3, no. 1, pp. $1-5,2004$.

[2] FAO, "Response of maize to magnesium and zinc application in the semi-arid zone of West Africa," in Case Studies from Four Countries in West Africa, FAO Regional Office, Accra, Ghana, 2000.

[3] C. A. Anane-Sakyi, A. A. Abunyewa, A. L. Nyamekye, and E. Y. Safo, "Integrated nutrient management: Preliminary results from a 2-year field trial using, cow dung, mineral fertilizer and maize test crop in the interior savannah zone of Ghana," Ghana Journal of Agricultural Science, vol. 1, pp. 161-164, 2005.

[4] S. K. Kimani, A. O. Esilaba, M. M. Odera, A. Kimenya, B. Vanlauwe, and A. Bationo, "Effects of organic and mineral sources of nutrients on maize yields in three districts of central Kenya," in Advances in Integrated Soil Fertility Management in Sub-Saharan Africa: Challenges and Opportunities, A. Bationo, B. Waswa, J. Kihara, and J. Kimetu, Eds., pp. 353-357, Springer, Dordrecht, The Netherlands, 2007.

[5] I. M. Tabu, A. Bationo, R. K. Obura, and J. K. Masinde, "Effects of rock phosphate, lime, and green manure on growth and yield of maize in a non-productive niche of a Rhodic Ferraisol in farmer's field," in Advances in Integrated Soil Fertility Management in Sub-Saharan Africa: Challenges and Opportunities, A.
Bationo, B. Waswa, J. Kihara, and J. Kimetu, Eds., pp. 449-456, Springer, Dordrecht, The Netherlands, 2007.

[6] E. Gilbert, L. C. Phillips, W. Roberts, M. T. Sara, M. Smale, and A. Stroud, Maize Research Impact in Africa. The Obscured Revolution Report Prepared for the Division of Food, Agriculture and Resource Analysis, Bureau of Africa, US Agency for International Development. AMEX International, Inc., 1993.

[7] E. A. Dennis, C. Anane-Sakyi, and G. Affi-Pungu, "The effect of cow dung and mineral fertilizers on yield of dry season gardening of onion in the Upper East Region of Ghana," in Proceedings of the 1st National Workshop on Food and Industrial Crops, October 1994.

[8] F. Adani, P. Genevini, G. Ricca, F. Tambone, and E. Montoneri, "Modification of soil humic matter after 4 years of compost application," Waste Management, vol. 27, no. 2, pp. 319-324, 2007.

[9] I. Celik, I. Ortas, and S. Kilic, "Effects of compost, mycorrhiza, manure and fertilizer on some physical properties of a Chromoxerert soil," Soil \& Tillage Research, vol. 78, no. 1, pp. 59-67, 2004.

[10] M. Agassi, G. J. Levy, A. Hadas et al., "Mulching with composted municipal solid wastes in Central Negev, Israel: I. effects on minimizing rainwater losses and on hazards to the environment," Soil \& Tillage Research, vol. 78, no. 1, pp. 103-113, 2004.

[11] A. A. Nel and H. L. Loubser, "The impact of crop rotation on profitability and production risk in the eastern and north western free state," Agrekon, vol. 43, no. 1, pp. 101-111, 2004.

[12] FAO, World Soil Resources: An Explanatory Note on the FAO World Soil Resources Map at 1:25,000 000 Scale, FAO, Rome, Italy, 1991.

[13] IITA, Selected Methods for Soil and Plant Analysis, No. 1, IITA, Ibadan, Nigeria.

[14] J. M. Bremner and D. R. Keeney, "Steam distillation methods for determination of ammonium, nitrate and nitrite," Analytica Chimica Acta, vol. 32, pp. 485-495, 1965.

[15] R. H. Bray and L. T. Kurtz, "Determination of total, organic, and available forms of phosphorus in soils," Soil Science, vol. 59, no. 1, pp. 39-46, 1945.

[16] D. W. Nelson and L. W. Sommers, "Total carbon, organic carbon and organic matter," in Methods of Soil Analysis, A. L. Page, R. H. Miller, and D. R. Keeney, Eds., pp. 301-312, American Society of Agronomy, Madison, Wis, USA, 1982.

[17] R. Tripp, "Data collection, site selection and farmer participation in on-farm experimentation," CIMMYT Economics Program Working Paper 82/1, CIMMYT, Mexico City, Mexico, 1982.

[18] E. Crawford and M. Kamuanga, Economic Analysis of Agronomic Trials for the Formulation of Farmer Recommendations, Michigan State University, 6th edition, 1988.

[19] D. N. Mugendi, P. K. R. Nair, J. N. Mugwe, M. K. O'Neill, and P. L. Woomer, "Alley cropping of maize with calliandra and leucaena in the subhumid highlands of Kenya: Part 1. Soilfertility changes and maize yield," Agroforestry Systems, vol. 46, no. 1, pp. 39-50, 1999.

[20] G. M. Muyayabantu, B. D. Kadiatu, and K. K. Nkongolo, "Response of maize to different organic and inorganic fertilisation regimes in monocrop and intercrop systems in Subsahara Africa Region," Journal of Soil Science and Environmental Management, vol. 3, no. 2, pp. 42-48, 2012. 
[21] A. P. Mallarino and J. Prater, "Corn and soybean grain yield, phosphorus removal, and soil-test responses to long-term phosphorus fertilization strategies," in Proceedings of the Integrated Crop Management Conference, pp. 241-253, November 2007.

[22] P. E. Otieno, J. W. Muthomi, G. N. Chemining'wa, and J. H. Nderitu, "Effect of rhizobia inoculation, farm yard manure and nitrogen fertilizer on nodulation and yield of food grain legumes," Journal of Biological Sciences, vol. 9, no. 4, pp. 326332, 2009.

[23] J. J. Kapkiyai, N. K. Karanja, P. L. Woomer, and J. N. Qureshi, "Soil organic carbon fractions in a long-term experiment and the potential for their use as a diagnostic assay in highland farming systems of Central Kenya," African Crop Science Journal, vol. 6, no. 1, pp. 19-28, 1998.

[24] F. Ofori and W. R. Stern, "Cereal-legume intercropping systems," Advances in Agronomy, vol. 41, pp. 41-90, 1987.

[25] W. T. Bowen, Estimating the Nitrogen Contribution of Legumes to Succeeding Maize on an Oxisol in Brazil, Cornell University, Ithaca, NY, USA, 1988. 


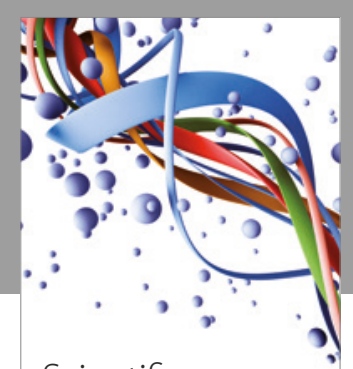

Scientifica
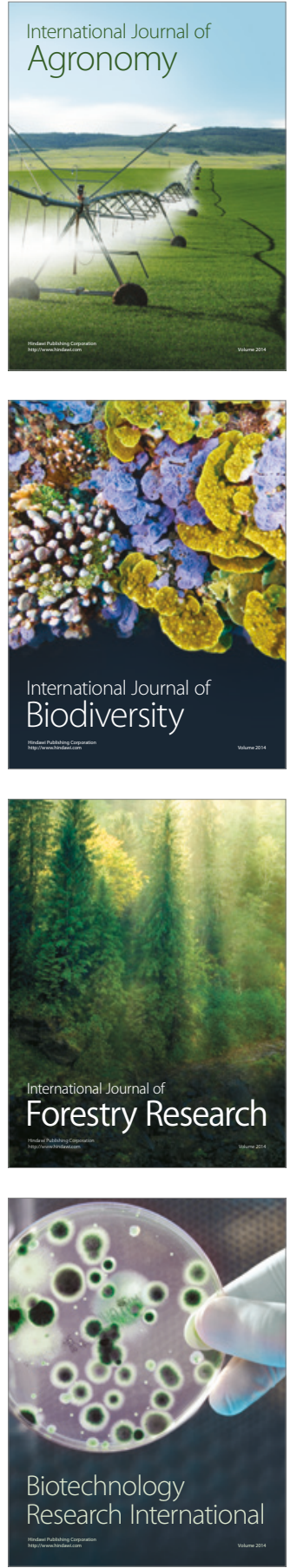
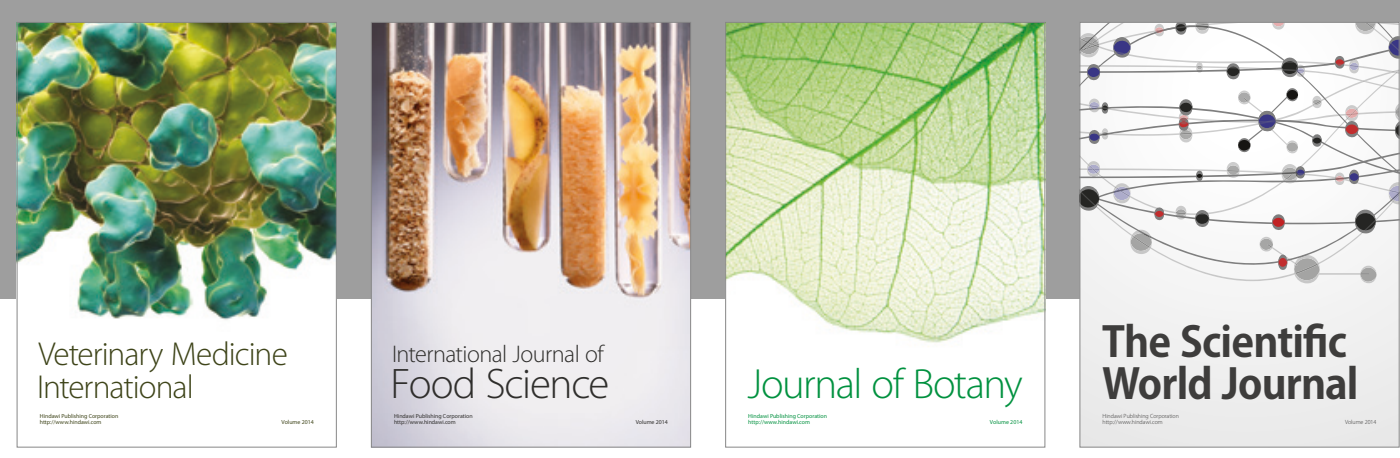

The Scientific

\section{World Journal}

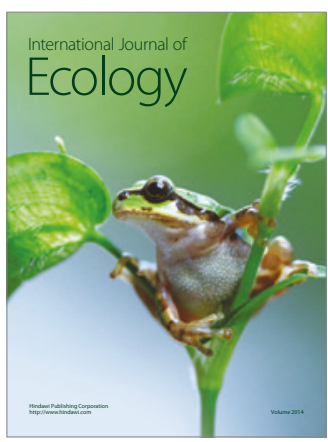

\section{Hindawi}

Submit your manuscripts at

https://www.hindawi.com
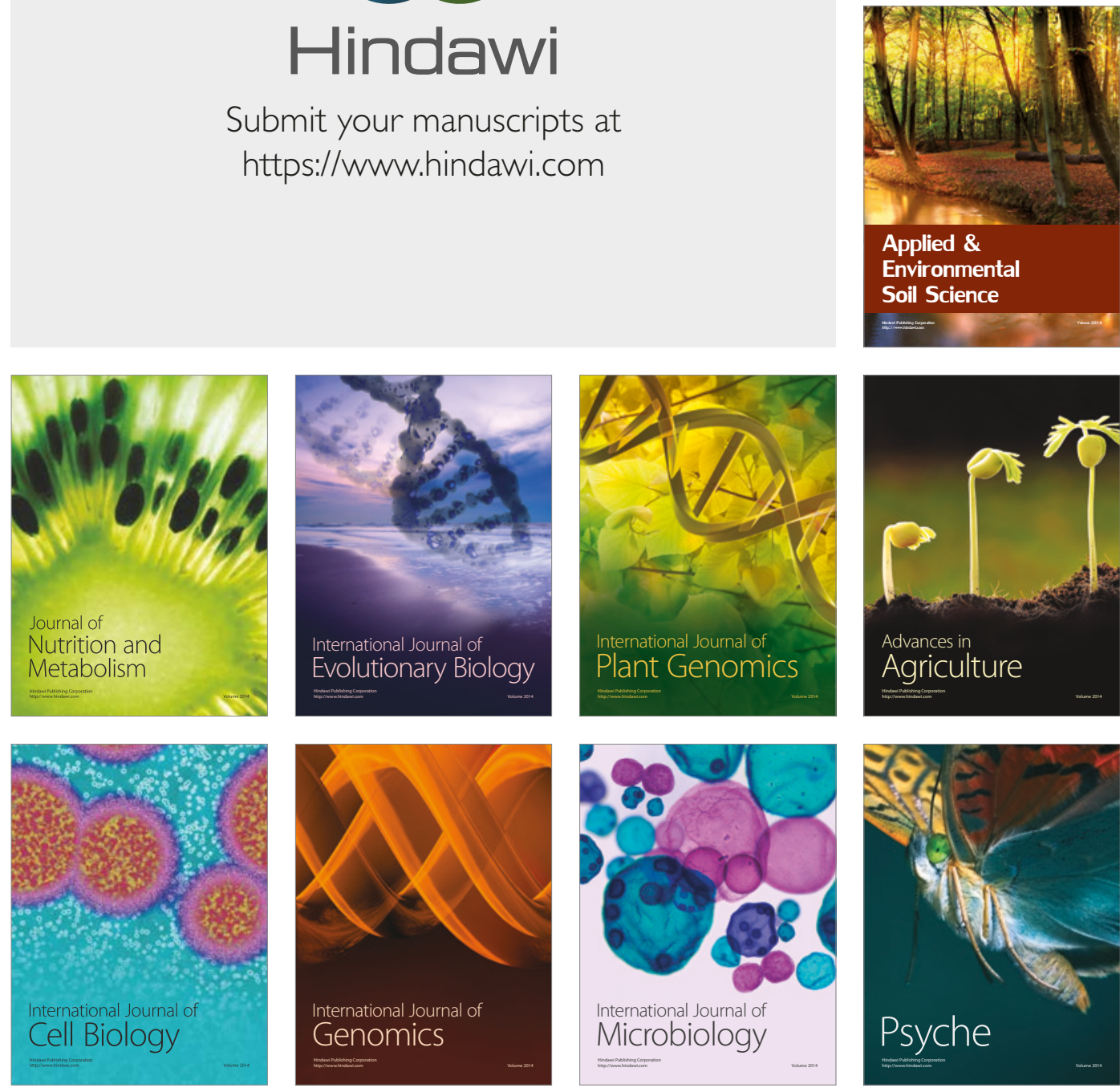

hternational Journal of Microbiology
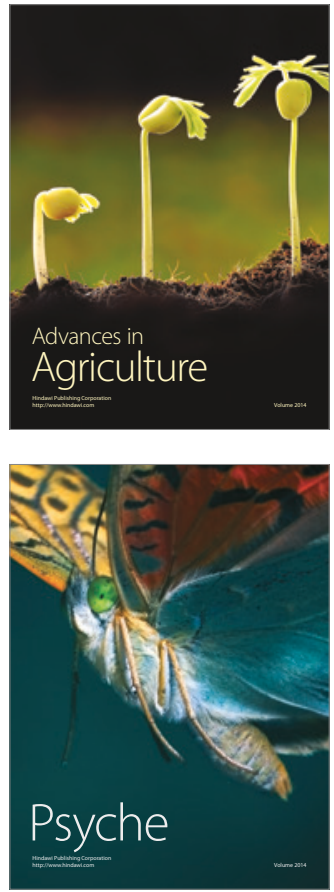